\title{
Comparative study of enteric viruses, coliphages and indicator bacteria for evaluating water quality in a tropical high-altitude system
}

\author{
Ana C Espinosa1, Carlos F Arias², Salvador Sánchez-Colón ${ }^{3}$ and \\ Marisa Mazari-Hiriart*1
}

Address: ${ }^{1}$ Instituto de Ecología, Universidad Nacional Autónoma de México, Circuito Exterior, Ciudad Universitaria, Coyoacán, 04510 México, DF, México, 2Instituto de Biotecnología, Universidad Nacional Autónoma de México, Av Universidad 2001, Col Chamilpa, 62210 Cuernavaca, Morelos, México and ${ }^{3}$ Consultoría Ambiental y Estadística, Cerrada de Cortés 43, Colonia Campestre Tlacopac, San Ángel, 01049 México, DF, México

Email: Ana C Espinosa - acespino@ecologia.unam.mx; Carlos F Arias - arias@ibt.unam.mx; Salvador Sánchez-

Colón - salvadorsanchezcolon@prodigy.net.mx; Marisa Mazari-Hiriart* - mazari@servidor.unam.mx

* Corresponding author

Published: 27 October 2009

Environmental Health 2009, 8:49 doi:10.1 186/1476-069X-8-49

This article is available from: http://www.ehjournal.net/content/8/l/49

(c) 2009 Espinosa et al; licensee BioMed Central Ltd.

This is an Open Access article distributed under the terms of the Creative Commons Attribution License (http://creativecommons.org/licenses/by/2.0), which permits unrestricted use, distribution, and reproduction in any medium, provided the original work is properly cited.
Received: 23 December 2008

Accepted: 27 October 2009

\begin{abstract}
Background: Bacteria used as indicators for pathogenic microorganisms in water are not considered adequate as enteric virus indicators. Surface water from a tropical high-altitude system located in Mexico City that receives rainwater, treated and non-treated wastewater used for irrigation, and groundwater used for drinking, was studied.

Methods: The presence of enterovirus, rotavirus, astrovirus, coliphage, coliform bacteria, and enterococci was determined during annual cycles in $200 \mathrm{I}$ and 2002. Enteric viruses in concentrated water samples were detected by reverse transcriptase-polymerase chain reaction (RT-PCR). Coliphages were detected using the double agar layer method. Bacteria analyses of the water samples were carried out by membrane filtration.

Results: The presence of viruses and bacteria in the water used for irrigation showed no relationship between current bacterial indicator detection and viral presence. Coliphages showed strong association with indicator bacteria and enterovirus, but weak association with other enteric viruses. Enterovirus and rotavirus showed significant seasonal differences in water used for irrigation, although this was not clear for astrovirus.
\end{abstract}

Conclusion: Coliphages proved to be adequate faecal pollution indicators for the irrigation water studied. Viral presence in this tropical high-altitude system showed a similar trend to data previously reported for temperate zones.

\section{Background}

At present, public health concerns remain focused on waterborne diseases, with incidence data in both developed and developing countries making gastroenteritis highly important. A diversity of enteric bacteria and viruses has been associated with outbreaks of waterborne gastroenteritis $[1,2]$. 
Since the late 19th century, bacteria have been used as indicators of water quality [3]. Although there are reports concerning the inadequacy of bacteria as microbiological water quality indicators [4], it has been recognized that they are indicators of a broad bacterial group and regular human microbiota [5]. Nevertheless, bacteria alone offer limited information regarding microbiological water quality as they do not reflect the presence of enteric viruses or protozoa [6].

The presence of viruses and other pathogens in the environment is an indicator of faecal pollution that poses a potential risk to the exposed population, since such pathogens do not constitute normal gastrointestinal microbiota, and are only excreted by sick individuals [7]. Rotavirus is recognized as being responsible for diarrheal disease in young children with a worldwide mortality rate of 600,000 per year [8]. Astrovirus is also considered one of the most important agents of viral gastroenteritis $[9,10]$, and is ranked second after rotavirus as the major cause of diarrheal disease in young children and adults [11]. While the actual contribution of rotavirus to total incidence of diarrheal disease is between $25 \%$ and $52 \%$, astrovirus is much lower being responsible for between $5 \%$ and $10 \%$ of cases [12].

In Mexico, during autumn and winter, which correspond to the cold-dry season, rotavirus has been reported as the main etiologic agent of diarrheal disease in children aged two years and under, and as has already been mentioned, it is responsible for approximately $25 \%-50 \%$ of all gastrointestinal cases $[13,14]$. Epidemiological studies show a seasonal incidence of bacterial diarrheal disease mainly during the summer months that coincides with the warmrainy season [15-17].

It is important to consider enteric viruses in water quality studies not only because of their incidence as causal agents for diarrheal disease $[8,13]$, but also due to their characteristics, which allow them to survive in the environment for long periods of time, and tolerate changing environmental conditions $[4,18]$.

Although it is not possible to establish a direct relationship between epidemiological and environmental data, it is important to consider microbial water quality in terms of water use. Furthermore, it is important to assess the potential risk to the exposed population, especially in developing countries, considering that recycled water has been associated with the presence and re-emergence of waterborne diseases worldwide [19].

Mexico is one of the main countries that reuse wastewater for irrigation of land used for crop cultivation, an area which has been calculated to be approximately 180,000 ha [20]. This practice is likely to increase, and therefore, it would be advisable to assess water quality in terms of both viral composition and load in order to decrease the associated risk to the population. For such assessment it would be necessary to evaluate the most adequate indicator from a public health perspective, whether it is bacterial or viral.

The aim of this study was to compare the presence of enterovirus, rotavirus, astrovirus, coliphages and indicator bacteria in a tropical high-altitude system, which supplies the Southern area of Mexico City with water for both irrigation and drinking.

\section{Methods}

The study area is located in the South of Mexico City. It is a tropical high-altitude aquatic system located at 2240 masl, between $19^{\circ} 02$ and $20^{\circ} 12^{\prime} \mathrm{N}$ and $98^{\circ} 28^{\prime}$ and $99^{\circ} 32^{\prime} \mathrm{W}$, covering an area of $1,479 \mathrm{~km}^{2}$. The average annual temperature is $16^{\circ} \mathrm{C}$, but the temperature fluctuates greatly during the day with an average maximum of $25^{\circ} \mathrm{C}$ and minimum of $8^{\circ} \mathrm{C}$. The rainy season mainly occurs during the summer and autumn months (May to October), while the rest of the year remains dry.

Agriculture and farming remain the main activities in this area with water being pumped from the canal network for surface irrigation. Flowers and vegetables are cultivated in the area with some of the latter being eaten raw. There are some domestic animals, as well as "conservation areas" that have been invaded by squatter settlements, a common practice as part of the urbanization process in developing countries.

\section{Water samples}

The presence of rotavirus, enterovirus and astrovirus, as well as the abundance of indicator bacteria in the water source and in water used for irrigation was determined from samples obtained during the cold-dry (November to February) and warm-rainy (May to October) seasons in 2001 and 2002. These seasonal categories were defined according to two meteorological parameters: temperature and rainfall $[21,22]$. Samples from water used for irrigation were obtained from ten sampling points, randomly selected from a regular grid of 250 observation points covering the Xochimilco canal network, which had been set up for previous studies in the area [23]. For viral detection, a 20 L volume was collected at each sampling point for each season per year. Samples for bacteriological analyses were collected at a depth of $40 \mathrm{~cm}$ in $1 \mathrm{~L}$ sterile polypropylene flasks.

Water source samples were obtained from ten wells randomly selected from the total of 60 wells that form part of the Mexico City water supply system. Samples were taken 
directly from the wells prior to chlorine disinfection. For each season and year, $1200 \mathrm{~L}$ of water was filtered through a 1 MDS electropositive filtering cartridge at each well (CUNO, Meriden, CO). Within six hours of sampling, the cartridges were transported cold $\left(4^{\circ} \mathrm{C}\right)$ to the laboratory. For bacterial analyses, $1 \mathrm{~L}$ samples were taken in sterile polypropylene containers. At each sampling point, $\mathrm{pH}$, temperature and conductivity were measured using a portable YSI $3500 \mathrm{pH}$-conductivity meter (Yellow Spring, OH) and dissolved oxygen measured with an YSI 51B oxygen meter (Yellow Spring, OH). In the laboratory, the 80 water samples (10 samples from irrigation water and 10 water source samples, both taken each season for two years) were analyzed for the following enteric viruses: enterovirus (EV); rotavirus (RV); and astrovirus (AST); and for indicator organisms including total coliform (TC), faecal coliform (FC), and enterococci (FE), as described below.

\section{RNA extraction and cDNA synthesis}

Water samples were filtered through electropositive Virosorb 1 MDS cartridges (CUNO, Meriden, CO). Once water samples were concentrated to a $30 \mathrm{~mL}$ volume, RNA was extracted using a Trizol LS reagent (Invitrogen, Carlsbad, CA) and chloroform. Aliquots of $300 \mu \mathrm{L}$ of water were mixed with $300 \mu \mathrm{L}$ of PBS $1 \times$ and shaken vigorously five times, leaving the vials on ice for one minute between each shaking, and then centrifuged at 12,000 $\times \mathrm{g}$ for five minutes. The upper phase containing RNA was transferred and $500 \mu \mathrm{L}$ of Trizol added, gently mixing for one minute before replacing on ice. This procedure was repeated five times. Subsequently, $100 \mu \mathrm{L}$ of chloroform was added gently and shaken vigorously five times.

Following centrifugation at $12,000 \times \mathrm{g}$ for five minutes, the upper phase was recovered and incubated with the same volume of isopropanol at $4^{\circ} \mathrm{C}$ for 30 minutes, and then centrifuged for 15 minutes at $12,000 \times \mathrm{g}$ at $4{ }^{\circ} \mathrm{C}$. The pellet was washed with $1 \mathrm{~mL}$ of absolute ethanol and centrifuged for a further five minutes at $12,000 \times \mathrm{g}$ at $4{ }^{\circ} \mathrm{C}$. Finally, the pellet was dried at room temperature and resuspended in $20 \mu \mathrm{L}$ RNAse free water, and stored at $-70^{\circ} \mathrm{C}$ until RT-PCR analysis took place.

cDNA synthesis (RT reaction) was performed in a $20 \mu \mathrm{L}$ reaction volume containing $1 \mu \mathrm{L}$ of RNA, $1 \mu \mathrm{L}$ of $5 \mathrm{pM}$ primer, and $9.9 \mu \mathrm{L}$ nuclease-free water (Invitrogen, Carlsbad, CA) at $70^{\circ} \mathrm{C}$ for 10 minutes. Subsequently, 8.1 $\mu \mathrm{L}$ of a mix containing $4 \mu \mathrm{L}$ of $5 \times$ first strand buffer [ 250 $\mathrm{mM}$ Tris- $\mathrm{HCl}$ (pH 8.3), $375 \mathrm{mM} \mathrm{KCl}, 15 \mathrm{mM} \mathrm{MgCl}_{2}$ l, $2 \mu \mathrm{L}$ $0.1 \mathrm{M} \mathrm{DTT}, 2 \mu \mathrm{L} 5 \mathrm{mM}$ dNTPs and $20 \mathrm{U}$ Super Script II reverse transcriptase (Invitrogen) was added. The reaction was carried out at $42^{\circ} \mathrm{C}$ for one hour and subsequently at $70^{\circ} \mathrm{C}$ for 15 minutes.

\section{cDNA amplification}

Polymerase chain reaction (PCR) was carried out in a 25 $\mu \mathrm{L}$ volume with a mix of $17.27 \mu \mathrm{L}$ nuclease-free water, 2.5 $\mu \mathrm{L} 10 \times$ buffer [100 mM Tris- $\mathrm{HCl}(\mathrm{pH} 8.3), 500 \mathrm{mM} \mathrm{KCl}$, $15 \mathrm{mM} \mathrm{MgCl}_{2}, 0.01 \% \mathrm{w} / \mathrm{v}$ gelatin], $1.6 \mu \mathrm{L} 5 \mathrm{mM}$ dNTPs, 1 $\mu \mathrm{L}$ of $25 \mathrm{pM}$ of each primer, and $0.625 \mathrm{U}$ of Ampli Taq Polymerase (Roche). The primers used to amplify the conserved region for group A that codes for the VP7 structural protein of rotavirus (RV) were as follows: forward (5GGCTTTAAAAGAGAGAATTTCCGTCTGG-3) and reverse (5-GATCCTGTTGGCCATCC-3) [24], for enterovirus (EV) the highly conserved region among picornaviruses 5'NCR forward (5-TCCGGCCCCTGAATGCGG-3) and reverse (5CACCGGATGGCCAATCCAAT-3) [24], and for astrovirus (AST) the conserved region of ORF2 forward (5-GGTGTCACAGGACCAAAACC-3) and reverse (5-TTAGTGAGCCACCAGCCATC-3) [25].

The amplification conditions included denaturation at $94^{\circ} \mathrm{C}$ for one minute and 33 cycles at $94^{\circ} \mathrm{C}$ for $30 \mathrm{sec}-$ onds, $50^{\circ} \mathrm{C}$ for 30 seconds and $72^{\circ} \mathrm{C}$ for 25 seconds, with a final elongation at $72^{\circ} \mathrm{C}$ for seven minutes. Agarose gels were stained with ethidium bromide and examined under ultraviolet light.

\section{Bacteriological water analyses}

Bacteriological analyses of TC, FC, and FE were carried out according to the membrane filtration method using selective media and following standard procedures [26]. The bacteriological culture media used were m-Endo (BBL), m-FC (BBL) and KF-Streptococcus Agar (BBL) according to manufacturer's instructions for TC, FC and FE respectively. Briefly, $1 \mathrm{~L}$ water samples were taken in sterilized polypropylene bottles. The samples were transported to the laboratory under cold conditions $\left(4^{\circ} \mathrm{C}\right)$ and processed in the within 6 hours of sampling at the most. When necessary samples were diluted, mainly for irrigation water, while $100 \mathrm{~mL}$ of drinking water samples were directly filtered. After filtration through a $0.45 \mu \mathrm{m}$ nitrocellulose membrane (Millipore), the media plates were incubated at $36^{\circ}$ for $24 \mathrm{~h}$ for TC, at $44.5^{\circ} \mathrm{C}$ for $24 \mathrm{~h}$ for $\mathrm{FC}$ and at $36^{\circ} \mathrm{C}$ for $48 \mathrm{~h}$ for FE.

\section{Detection of Coliphages}

Coliphages were detected from concentrated water samples using Escherichia coli K12 Hfr (ATCC) as the host bacterium according to the double layer agar method. Briefly, $5 \mathrm{~mL}$ of Trypticase peptone semisolid agar (1\%) containing $500 \mu \mathrm{L}$ of $\mathrm{K} 12$ in exponential growth phase and 500 $\mu \mathrm{L}$ of concentrated water sample were poured onto Trypticase peptone solid agar. Plates were incubated at $37^{\circ} \mathrm{C}$ for $18 \mathrm{~h}$ and the coliphage plaques counted. 


\section{Statistical analysis}

Data were analyzed using a generalized linear model approach $[27,28]$. First, we tested for differences between years, between seasons and between seasons within each year (year $\mathrm{X}$ season interaction) in the occurrence of viruses or the abundance of indicator bacteria. For viruses, the response variable (presence/absence) was assumed to follow a Bernoulli distribution; the abundance of bacteria was assumed to follow a quasiPoisson distribution (to compensate for overdispersion when a Poisson distribution was used). A full factorial model with factors Year (2001 vs. 2002) and Season (cold-dry vs. warm-rainy) was fitted to each response variable (occurrence of rotavirus, enterovirus and astrovirus; abundance of TC, FC, and FE) separately. The terms' significance was judged with basis on the change in deviance that its deletion from the model produced, which approximately follows a Chisquare distribution [27].

Second, in order to examine the relationship between the occurrence of viruses or the abundance of bacteria and the physicochemical environmental variables recorded, loglinear (for bacteria abundance, with a quasiPoisson distribution) or logit (for viruses occurrence, with a Bernoulli distribution) models were separately fitted to each response variable (abundance of $\mathrm{TC}, \mathrm{FC}$, and FE; occurrence of rotavirus, enterovirus and astrovirus) with the environmental variables (temperature, conductivity, $\mathrm{pH}$ and Oxygen concentration) as predictors; for viruses' models, the abundance of indicator bacteria (i.e., TC, FC and FE) were also included as predictors. In each case, predictor variables significantly related to the response varia- ble were identified also with basis on the change in deviance that its deletion from the model produced.

Finally, simple two-way analyses of variance were used to test for differences between years, between seasons and between seasons within each year in the means of the physicochemical environmental variables recorded $(\mathrm{pH}$, Oxygen concentration, temperature and conductivity).

\section{Results \\ Water used for irrigation}

Deviance analysis resulting from the generalized linear model approach showed no significant differences between years, between seasons, nor between seasons within each year in terms of AST presence. However, there were significant differences between seasons when the presence of both EV and RV were considered. The presence of these pathogens was significantly more frequent during the cold-dry season ( 0.75 and 0.35 , respectively) than in the warm-rainy season $(0.10$ and 0.05 , respectively) (Figure 1).

The presence of AST and RV showed no significant relationship with either the environmental variables recorded ( $\mathrm{pH}$, temperature, conductivity and dissolved oxygen concentration) or with the abundance of bacterial indicators. By contrast, EV presence was significantly related to temperature (Figure 2) but not to the abundance of any of the bacterial indicators.

As for bacterial indicators, all samples were positive for the three bacterial groups, indicating continuous faecal contamination of the water used for irrigation. Deviance

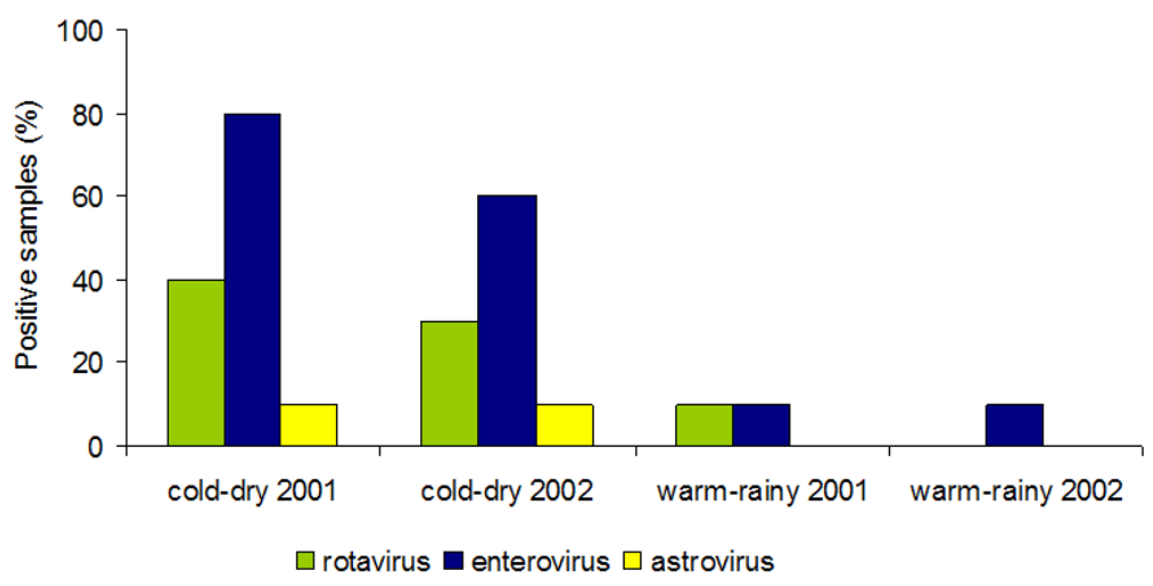

Figure I

Percentage of RT-PCR positive samples. Rotavirus (RV), enterovirus (EV) and astrovirus (AST) in water used for irrigation over annual cycles (200I and 2002). The Astrovirus genome was not detected either of the two warm-rainy seasons, and the genome rotavirus was not detected during the 2002 warm-rainy. 


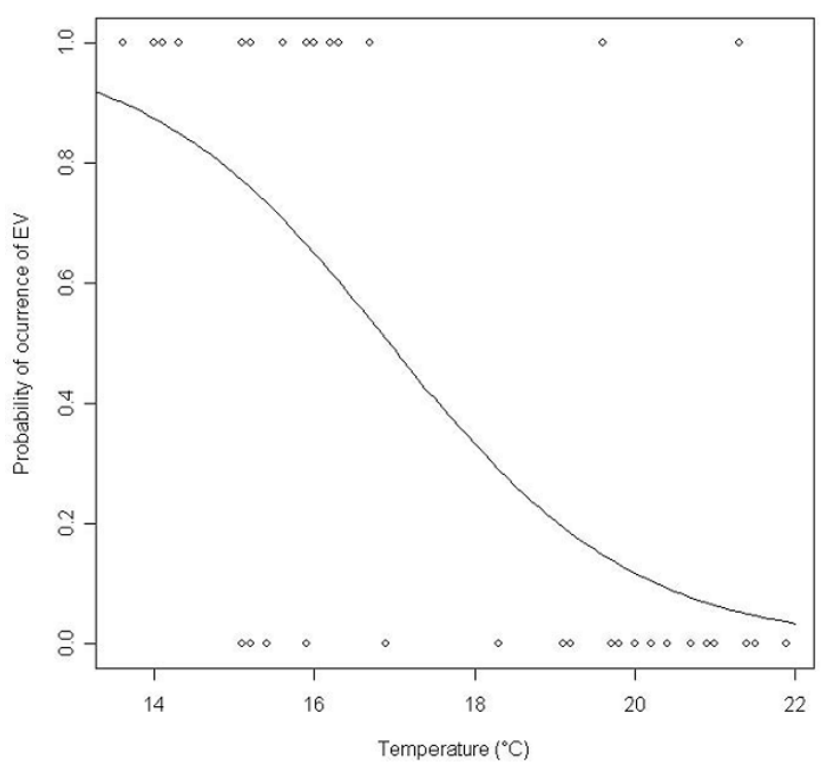

Figure 2

Relationship between the occurrence of EV in irrigation waters and temperature. Points represent observed values $(I=$ presence, $0=$ absence $)$, while the continuous curve represents the logit model describing relationship between the probability of occurrence of EV and temperature: $\mathrm{P}=\exp \left(\mathrm{I} \mathrm{I} .1268-0.657^{*}\right.$ Temperature $) /(\mathrm{I}+$ $\exp ($ I I.I268-0.657*Temperature) ).

analysis showed no significant differences between years, between seasons, or between seasons within each year when the abundance of faecal coliform (FC) or enterococci (FE) were considered. However, the abundance of these bacterial groups was significantly related to $\mathrm{pH}$. By contrast, there were significant differences in the abun- dance of TC between years and between seasons. TC was significantly more abundant in 2001 than in 2002, and during the dry season than during the rainy season (Figure 3 ). However, the abundance of TC was not significantly related to any of the environmental variables recorded ( $\mathrm{pH}$, temperature, conductivity and dissolved oxygen concentration).

Table 1 shows the association between enteric virus, coliphages and indicator bacteria when detected in irrigation water. This association is clear as reflected by the p-value. Positive samples for coliphages coincided more frequently with the positive samples for indicator bacteria than $\mathrm{EV}$, or the other enteric viruses.

\section{Water used for drinking}

No viruses were detected in the drinking water wells prior to chlorination. According to the physicochemical parameters: $\mathrm{pH}$; temperature; dissolved oxygen concentration; and conductivity; there were no differences in prevailing conditions for each sampling station. This demonstrated that there was no seasonal difference in the conditions pertaining to these sources of drinking water.

Indicator bacteria were detected in the pre-chlorinated drinking water samples. Results of TC, FC, and FE presence (Table 2) show that FE were most frequently isolated and most abundant, with five positive samples in 2001 and 13 positive samples in 2002. In terms of FE abundance, deviance analysis showed no significant difference between years, between seasons or between seasons within each year. Similarly, no significant relationship was found between the abundance of FE and any of the environmental variables $(\mathrm{pH}$, temperature, conductivity and dissolved oxygen concentration). There were signifi-

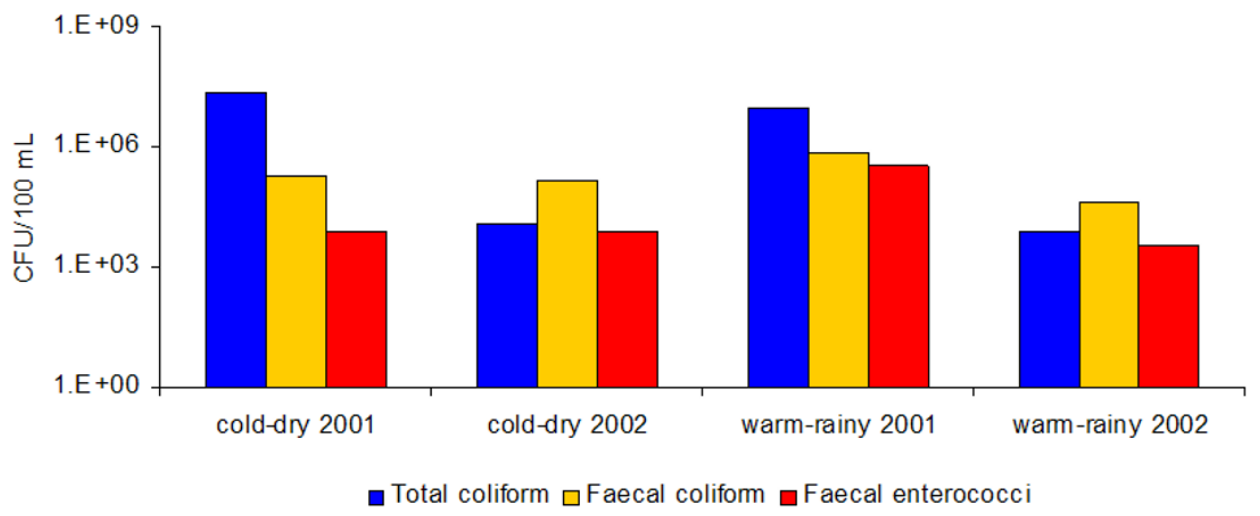

Figure 3

Indicator bacteria in irrigation water. Counts of total coliforms (TC), faecal coliforms (FC) and enterococci (FE) in water used for irrigation over two seasons each year. Bacterial counts were determined by filtration membrane method and standard culture media. 
Table I: Association of enteric viruses, bacteria and coliphage in irrigation water.

\begin{tabular}{|c|c|c|c|c|c|}
\hline \multirow[b]{3}{*}{ Microorganisms } & \multicolumn{4}{|c|}{ Coliphages } & \multirow[b]{3}{*}{$p$ value } \\
\hline & \multicolumn{2}{|c|}{$\begin{array}{c}\text { Negative } \\
(n=40)\end{array}$} & \multicolumn{2}{|c|}{$\begin{array}{l}\text { Positives } \\
(n=40)\end{array}$} & \\
\hline & $\mathbf{n}$ & $\%$ & $\mathbf{N}$ & $\%$ & \\
\hline TC & 1 & 2.5 & 33 & 82.5 & 0.0003 \\
\hline FC & 0 & 0 & 35 & 87.5 & 0.0000 \\
\hline FE & 0 & 0 & 40 & 100 & 0.0000 \\
\hline EV & 3 & 7.5 & 16 & 40 & 0.0182 \\
\hline $\mathrm{RV}$ & 7 & 17.5 & 7 & 17.5 & 0.1502 \\
\hline AST & 7 & 17.5 & 2 & 5 & 0.4587 \\
\hline
\end{tabular}

cant differences between years and between seasons in both TC and FC abundance. These bacteria types were significantly more abundant in 2002 than in 2001, and showed a higher presence during the dry season than the rainy season. TC and FC abundance were also significantly related to variation in conductivity.

\section{Physicochemical parameters}

The physicochemical parameters recorded were temperature, conductivity, $\mathrm{pH}$, and dissolved oxygen. Average values for each season, year, and water type are shown in Table 3.

When water used for irrigation was considered, the twoway variance analysis showed no significant differences between seasons or between years in terms of average $\mathrm{pH}$ or average dissolved oxygen concentration. By contrast, average temperature during the cold-dry season was significantly $(\mathrm{p}<0.001)$ lower than during the warm-rainy season.

Significant variations between seasons within each year in terms of average conductivity were also found; in 2001 there were no significant differences between seasons but, in 2002, average conductivity was significantly higher dur- ing the cold-dry season suggesting that there was a variation between years for some parameters.

For water source samples, analyses showed no significant variations in terms of average temperature. By contrast, there were significant differences between years $(\mathrm{p}<$ $0.001)$ and between seasons $(p<0.01)$ in terms of average $\mathrm{pH}$. Significant variations between seasons within each year for average dissolved oxygen concentration were also found. In 2001, average conductivity was significantly higher during the warm-rainy season, whereas in 2002 there were no significant differences between seasons. Finally, average conductivity was significantly higher $(\mathrm{p}=$ 0.011 ) during the cold-dry seasons.

\section{Discussion}

The Mexico City area, where the study was carried out has been classified as a tropical highland [29], with an altitude of 2240 masl and climatic conditions, with a cold-dry autumn and winter followed by a warm-dry spring and a warm-wet summer.

The current study used two basic meteorological parameters to define the seasonal categories (cold-dry and warmrainy); temperature and rainfall as reported by the official National Meteorological System (Sistema Meteorológico Nacional) $[21,22]$.

Treated wastewater represents the most important input to the aquatic system; a process that does not consider virus elimination. There are also raw wastewater discharges directly from households $(2,015$ houses with about 4.5 persons) that a lack sewer system [30] and it is estimated that 2,116 kg of faeces enter the aquatic system daily. Due to the continuous faeces contribution and enteric virus detection predominantly in the cold-dry season, a seasonal pattern regarding viral presence is suggested. On the other hand, studies of diarrheal disease caused by rotavirus and astrovirus in young children from Southern Mexico City [14,31] showed higher rates in the autumn and winter months [14]. This increased incidence

Table 2: Total bacterial counts (CFU/100 mL) for TC, FC and FE in the water source.

\begin{tabular}{|c|c|c|c|c|c|c|}
\hline \multirow[t]{2}{*}{ Year/season } & \multicolumn{2}{|r|}{ TC } & \multicolumn{2}{|r|}{ FC } & \multicolumn{2}{|r|}{ FE } \\
\hline & $+/ \mathbf{n}$ & CFU/I00 mL & $+/ n$ & CFU/I00 mL & $+/ \mathbf{n}$ & CFU/I00 mL \\
\hline \multicolumn{7}{|l|}{2001} \\
\hline warm-rainy & $0 / 10$ & 0 & $1 / 10$ & 1 & $1 / 10$ & 1 \\
\hline cold-dry & $1 / 10$ & 1 & $0 / 10$ & 0 & $4 / 10$ & 101 \\
\hline \multicolumn{7}{|l|}{2002} \\
\hline warm-rainy & $2 / 10$ & 24 & $1 / 10$ & 1 & $7 / 10$ & 370 \\
\hline cold-dry & $4 / 10$ & 404 & $4 / 10$ & 53 & $6 / 10$ & 216 \\
\hline
\end{tabular}

$+/ \mathrm{n}$ positive samples with respect to total number of samples 
Table 3: Physicochemical parameters registered in water samples.

\begin{tabular}{|c|c|c|c|c|}
\hline \multirow[t]{2}{*}{ Parameter } & \multicolumn{2}{|l|}{2001} & \multicolumn{2}{|l|}{2002} \\
\hline & Warm-rainy & Cold-dry & Warm-rainy & Cold-dry \\
\hline \multicolumn{5}{|l|}{ Irrigation } \\
\hline Temperature $\left({ }^{\circ} \mathrm{C}\right)$ & 20.77 & 15.26 & 19.90 & 15.15 \\
\hline $\mathrm{pH}$ & 7.53 & 7.85 & 7.92 & 7.78 \\
\hline Conductivity $\mu \mathrm{S} / \mathrm{cm}$ ) & 658.00 & 711.00 & 477.20 & 727.10 \\
\hline Dissolved oxygen (mg/L) & 3.27 & 2.82 & 3.93 & 3.94 \\
\hline \multicolumn{5}{|l|}{ Drinking water } \\
\hline Temperature $\left({ }^{\circ} \mathrm{C}\right)$ & 16.86 & 15.83 & 16.02 & 16.41 \\
\hline $\mathrm{pH}$ & 6.95 & 6.78 & 7.83 & 7.34 \\
\hline Conductivity $(\mu \mathrm{S} / \mathrm{cm})$ & 379.30 & 315.40 & 463.30 & 293.10 \\
\hline Dissolved oxygen (mg/L) & 3.48 & 4.57 & 3.52 & 3.09 \\
\hline
\end{tabular}

reflects the findings of the current study in which viral presence is higher in the cold-dry season.

Unfortunately in Mexico, the National Epidemiological Surveillance System [32] does not report epidemiological information that would indicate the actual number of viral gastroenteritis cases, nor their seasonal behaviour. This is despite the fact that gastrointestinal disease at a local level (Mexico City) is among the 20 main causes of hospitalization [33].

During the cold-dry season the average low temperature was $4^{\circ} \mathrm{C}$ with an average precipitation of less than $10 \mathrm{~mm}$ $[21,22]$, which had an effect on the presence of both bacteria and enteric viruses. This is related to lower water levels, higher concentration of organic matter [23], and lower temperature [34], the latter favouring the presence of enteric viruses [35]. These measurements of temperature and precipitation support the current study for $\mathrm{EV}$ and RV, which showed a higher presence during the colddry season. Conversely, AST was present in only $10 \%$ of the samples. The variation between the frequencies of different viruses can be associated with structural virus characteristics, in that the RV capsid presents three protein layers, as compared with only one for AST. The higher frequency of EV could be related to the massive polio vaccination campaigns that are carried out in Mexico three times a year for children of less than five years old. In previous studies, polio vaccine was isolated from both wastewater and river water two or three following the vaccination campaign [36-38]. Other studies are needed to ensure that the EV detected in the water samples used for irrigation corresponds to the vaccine type.

In the warm-rainy season, the temperature can reach an average of $24^{\circ} \mathrm{C}[21,22]$, while rainfall can reach 1,500 $\mathrm{mm}$. At the beginning of the rainy season, two natural processes are evident in the canal system: soil washing and water dilution. These promote an increase in bacterial density and counts in water, while towards the middle of the rainy season, bacterial density decreases due to dilution. Although warm-rainy temperature favours bacterial growth, enteric viruses could be damaged by rising temperatures, as proved previously, when EV and RV were studied in fresh water at $22^{\circ} \mathrm{C}$ and $20^{\circ} \mathrm{C}[39,40]$. EV, RV and AST were practically absent during the warm-rainy season in both years.

The rainfall, plus a significant increase in temperature compared with that of the cold-dry season, contributes to the presence of these viruses in the water used for irrigation from this tropical high-altitude area. Additionally, solar radiation, especially UVB (320-280 nm), has recently been reported as an important parameter that affects viral presence and infectivity $[41,42]$, another environmental parameter that should be included in future studies.

It is important to point out that TC is a group that includes enteric and non-enteric bacteria [43], and the lower TC counts could be related to interference of non-coliform bacteria that inhibit coliform bacteria growth, as has been shown by Burlingame et al. [44], when m-Endo medium was used. Moreover, FC cultivated in m-FC medium at $44.5^{\circ} \mathrm{C}$ has been reported to promote non-E. coli thermophilic growth [45], which can produce a FC overestimation or a false positive reading. The culture media used are those recommended by Standard Methods [26] and also correspond to the official Mexican methods [46] for the enumeration of TC and FC in water samples. However, the use of other methods to measure indicator bacteria that show more specific results, mainly for water from tropical and subtropical areas [45], is recommended for subsequent studies.

The results obtained in this study showed that coliphages can be used as indicators of faecal contamination in reused water, in a complementary role to indicator bacte- 
ria. There are publications that support coliphages usefulness as faecal indicators [47-50], because based on their presence it is possible to infer faecal contamination. Our results are in agreement, shown by the significant correlation between coliphages and faecal coliforms.

According with the results, coliphages are useful as index or model organism of the presence of $\mathrm{EV}$, due to the significant relationship showed. These agree with results reported for coliphages and enterovirus $[51,52]$ where there is also highlighted the similarities in physical particle characteristics, as well as resistance to wastewater treatment; which support the idea of using coliphages as enteric viruses index, and also as a process indicator [48].

Coliphages have been shown to be complementary or equivalent to other indicators, therefore it is highly advisable to include them as faecal pollution indicators and also as index of enteric virus for water quality monitoring programs.

Mexico is considered to be a leading country in terms of wastewater recycling [20]. This practice does not appear to be on the wane and it is envisaged that more land will make use of wastewater for irrigation in the future. Mexican regulations [53-55] and World Health Organization guidelines for irrigation [56] consider $\leq 1000 \mathrm{CFU} / 100$ $\mathrm{mL}$ coliform bacteria as an acceptable limit for the irrigation of land that is used to grow crops. However, according to the results discussed here, this limit has been exceeded in the study area. The enteric virus and bacterial survival on vegetable surfaces [57], constitutes a serious health risk for agricultural workers, as well as for consumers [58].

Enteric viruses were not detected in the water sources during the seasons and years studied. Nevertheless, the relevance of this area as a source of drinking water makes it important to monitor viral presence regularly. Coliphages may provide adequate viral indicators representing the large group of EV, but further evaluation is required before they can be used for this purpose; tests that were not performed as part of this study due to time and financial constraints.

Indicator bacteria detected in water sources did not show any seasonal trends. The higher FE frequency suggests that these could be better bacterial contamination indicators as compared with TC and FC levels in the region. The water extraction wells are located in the transition area, where sedimentary soil composition is known to favour water infiltration. This can affect groundwater quality because the sewage system is insufficient for the growing population of these areas, and does not exist at all in squatters settlements. Sewer breakages, which are frequent occurrences, could explain the presence of indicator bacteria in the drinking water sources, as well as being important for viral contamination. Groundwater as a source for drinking water presents more stable conditions as compared with surface water; non-solar irradiation and relatively low temperatures are favourable for enteric viral presence and infectivity [18]. In these circumstances, preventive actions should be taken.

\section{Conclusion}

Enterovirus, rotavirus, astrovirus, total coliform, faecal coliform, enterococci and coliphages considered in this study were present in water to be used for irrigation.

The abundant presence of indicator bacteria and enteric viruses in irrigation water proves a continuous raw residual water supply to the aquatic system.

Viral presence in irrigation water, for the specific tropical highland system under study, is similar to that previously reported for temperate zones, during the colder months.

The detection of indicator bacteria in the sources of drinking water shows the contribution of faecal matter in the aquifer and reinforces the need for an adequate disinfection process in order to ensure good water quality in the public supply system.

Analysis to identify the presence of coliphages as indicators of faecal contamination is recommended. These should be considered as complementary to bacterial indicators, and to reflect the general survival conditions of enteric viruses. The fact that coliphages are tolerant to wastewater treatment makes them suitable indicators for the evaluation of recycled water to be used for irrigation and recreational purposes.

This low-cost strategy of using viral and bacterial indicators to confirm water quality for drinking and irrigation is attractive and advisable for low income countries, reflected in a public health benefit.

\section{Abbreviations}

AST: astrovirus; cDNA: complementary DNA; EV: enterovirus; FC: faecal coliform; FE: enterococci; NCR: non code region; ORF: open reading frame; PCR: polymerase chain reaction; RT: reverse transcriptase; RT-PCR: reverse transcriptase-polymerase chain reaction; $\mathrm{RV}$ : rotavirus; $\mathrm{TC}$ : total coliform; UVB: ultraviolet B radiation.

\section{Competing interests}

The authors declare that they have no competing interests. 


\section{Authors' contributions}

ACE and MMH conceived and designed this study, performing some preliminary assays. ACE contributed to the acquisition of field and experimental data, and carried out the analytical work. ACE initiated data interpretation, and drafted and revised the manuscript. $\mathrm{MMH}$ and CFA offered analytical suggestions, assisted with the interpretation of results, and made critical revisions to the manuscript suggesting details for the final draft. SSC contributed to statistical analyses and interpretation of data. All authors read and approved the final manuscript before submission.

\section{Acknowledgements}

AC Espinosa was a recipient of a graduate student fellowship from the Consejo Nacional de Ciencia y Tecnología (CONACyT, México). The authors would like to acknowledge the support of the Consejo Nacional de Ciencia y Tecnología (CONACyT, México) in enabling them to carry out project 32505-T from 1999-200I, and the Dirección de Asuntos del Personal Académico of the Universidad Nacional Autónoma de México (UNAM) for financial support with grant IN-219303 from 2003-2005. We also wish to thank P Islas, P Cisneros, and J Aguilar for their invaluable help in the field and laboratory work.

\section{References}

I. Liang JL, Dziuban EJ, Craun GF, Hill V, Moore MR, Gelting RJ, Calderon RL, Beach MJ, Roy SL, Centers for Disease Control and Prevention $(C D C)$ : Surveillance for waterborne disease and outbreaksassociated with drinking water and water not intended for drinking--United States, 2003-2004. MMWR Surveill Summ 2006, 55:3I-65.

2. Hewitt J, Bell D, Simmons GC, Rivera-Aban M, Wolf S, Greening GE: Gastroenteritis outbreak caused by waterborne norovirus at a New Zealand ski resort. Appl Environ Microbiol 2007, 73:7853-7857

3. Medema GJ, Payment P, Dufour A, Robertson W, Waite M, Hunter $P$, Kirby $R$, Andersson $Y$ : Safe drinking water: an ongoing challenge. In Assessing microbial safety of drinking water. Improving approaches and methods OCDE, WHO. Cornwall, IWA Publishing; 2003:12-47.

4. Skraber S, Gassiolloud B, Schwartzbrod L, Gantzer C: Survival of infectious Poliovirus- $I$ in river water compared to the persistence of somatic coliphages, thermotolerant coliforms and Poliovirus-I genome. Water Res 2004, 38:2927-2933.

5. Gerba C: Indicator microorganisms. In Environmental Microbiology Edited by: Maier RM, Pepper IL, Gerba CP. China. Academic Press; 2009:485-502.

6. Borchardt MA, Bertz PD, Spencer SK, Battigelli DA: Incidence of enteric viruses in groundwater from household wells in Wisconsin. Appl Environ Microbiol 2003, 69: I I72-I I 80.

7. Abad FX, Pintó RM, Villena C, Bosch A: Astrovirus survival in drinking water. Appl Environ Microbiol 1997, 63:31 I9-3 I22.

8. Parashar UD, Gibson ChJ, Bresee JS, Glass RI: Rotavirus and severe childhood diarrhea. Emerg Infect Dis 2006, I 2:304-306.

9. Foley B, O'Mahony J, Morgan SM, Hill C, Morgan JG: Detection of sporadic cases of Norwalk-like virus (NLV) and astrovirus infection in a single Irish hospital from 1996 to 1998. J Clin Virol 2000, 17:109-117.

10. Gofti-Laroche L, Gratacap-Cavallier B, Demanse D, Genoulaz O, Seigneurin JM, Zmirou D: Are waterborne astrovirus implicated in acute digestive morbidity (E.M.I.R.A. study)? J Clin Virol 2003, 27:74-82.

11. Matsui SM, Greenberg HB: Astroviruses. In Virology Edited by: Fields BN, Knipe DM, Howley PM. Philadelphia, Lippincott-Raven Publishers; 1996:81I-824.

12. Méndez E, Arias CF: Astroviruses. In Virology Edited by: Knipe DM, Howley PM, Griffin DE, Lamb RA, Martin MA, Roizman B, Straus SE. Philadelphia, Lipincott Willimas and Wilkins; 2007:981-1000.
13. LeBaron CW, Lew J, Glass GI, Weber JM, Ruiz-Palacios G, the Rotavirus Study Group: Annual Rotavirus Epidemic Patterns in North America. JAMA 1990, 264:983-988.

14. Villa S, Guiscafré H, Martínez H, Muñoz O, Gutiérrez G: Mortalidad estacional por diarrea entre niños mexicanos. Bull World Health Organ 1999, 77:375-380.

15. Calva J]: Las enfermedades diarréicas en niños mexicanos. Asoc Mex Infectol Microbiol Clin 1998, 1998: I2-17.

16. Guerrero L, Calva J], Morrow AL, Velásquez R, Tuz-Dzib F, LópezVidal Y, Ortega H, Arroyo H, Cleary TG, Pickering LK, Ruiz-Palacios G: Asymptomatic Shigella infections in a cohort of Mexican children younger than two years of age. Pediatr Infect Dis J 1994, 13:597-602.

17. López-Vidal Y, Calva JJ, Trujillo A, Ponce de León A, Ramos A, Svennerholm AM, Ruiz-Palacios G: Enterotoxins and adhesins of enterotoxigenic Escherichia coli : are they risk factors for acute diarrhea in the community? J Infect Dis 1990, 162:442-447.

18. Espinosa AC, Espinosa R, Maruri-Avidal L, Méndez E, Mazari-Hiriart $M$, Arias CF: Infectivity and genome persistence of rotavirus and astrovirus in drinking and irrigation water. Water Res 2008, 42:2618-2628.

19. Baggi F, Demarta A, Peduzzi R: Persistence of viral pathogens and bacteriophages during sewage treatment lack correlation with indicator bacteria. Res Microbiol 200I, I 52:743-75I.

20. Jiménez B: Irrigation in developing countries using wastewater. Int Rev Environ Strat 2006, 6:229-250.

21. CNA: 2001 [http://smn.cna.gob.mx/]. May 2008

22. CNA: 2002 [http://smn.cna.gob.mx/]. May 2008

23. Mazari-Hiriart M, Ponce-de-León S, López-Vidal Y, Islas-Macías $P$, Amieva-Fernández RI, Quiñones-Falconi F: Microbiological Implications of Periurban Agriculture and Water Reuse in Mexico City. PLoS ONE 2008, 3:e2305. doi:I0.137I/journal.pone.0002305

24. LeGuyader F, Dubois E, Menard D, Pommepuy M: Detection of hepatitis $A$ virus, rotavirus and enterovirus in naturally contaminated shellfish and sediment by reverse transcriptionseminested PCR. Appl Environ Microbiol 1994, 60:3665-367l.

25. Noel JS, Lee TW, Kurtz JB, Glass RI, Monroe SS: Typing of human astroviruses from clinical isolates by immunoassay and nucleotide sequencing. J Clin Microbiol 1995, 33:797-80I.

26. APHA: Standard Methods for Examination of Water and Wastewater. 20th edition. Washington, D.C. APHA, AWWA; 1998.

27. Crawley MJ: Statistics. An introduction using R New York: John Wiley; 2005.

28. Crawley MJ: Glim for ecologists Oxford: Blackwell Scientific Publications; 1993.

29. Blair T: Climatology: General and Regional Wisconsin: Blair Press; 2007.

30. INEGI. 2005 Conteo de Población y Vivienda 2005 [http:// www.inegi.org.mx/inegi/default.aspx? $=$ est\&c $=10215]$.

3I. Walter JE, Michell DK, Guerrero ML, Berke T, Matson DO, Monroe SS, Pickering LK, Ruiz-Palacios G: Molecular Epidemiology of Human Astrovirus Diarrhea among Children from a Periurban Community of Mexico City. J Infect Dis 200I, 183:68I-686.

32. SINAVE [http://www.dgepi.salud.gob.mx/boletin/boletin.htm]

33. GDF: Agenda Estadística. Secretaría de Salud, D F. México 2008 [http://www.salud.df.gob.mx/ssdf/media/Agenda2008/].

34. Barcina I, Arana I, Iriberri J, Egea L: Factors affecting the survival of $E$. coli in a river. Hydrobiol 1986, I 41:249-253.

35. Ward RL, Knowlton DR, Winston PE: Mechanism of inactivation of enteric viruses in fresh water. Appl Environ Microbiol 1986, 52:450-459.

36. Jiménez $\mathrm{P}$, Más $\mathrm{P}$, Sarmiento L, Bello $\mathrm{M}$, Palomera RE, Barrios J: Aportes al conocimiento acerca de la permanencia y circulación del poliovirus vacunal en el ambiente. Rev Cubana Med Trop 2001, 53:118-121.

37. Yoshida H, Horie H, Matsuura K, Kitamura T, Hashizume S, Miyamura $\mathrm{T}$ : Prevalence of vaccine-derived polioviruses in the environment. J Gen Virol 2002, 83: I I07-IIII.

38. Pavlov DN, Van Zyl WB, van Heerden J, Grabow WOK, Ehlers MM: Prevalence of vaccine-derived polioviruses in sewage and river water in South Africa. Water Res 2005, 39:3309-3319.

39. Raphael RA, Sattar SA, Springthope VS: Long-term survival human rotavirus in raw and treated river water. Can J Microbiol 1985, 3 I: 124-I 28. 
40. Hurst C], Benton WH, McClellan KA: Thermal and water sources effects upon the stability of enterovirus in surface freshwaters. Can J Microbiol 1989, 35:474-480.

4I. Hijnen WAM, Beerendonk EF, Medema GJ: Inactivation credit of UV radiation for viruses, bacteria and protozoan (oo)cysts in water: a review. Water Res 2006, 40:3-22.

42. Davies-Colley RJ, Craggs RJ, Park J, Sukias JPS, Nagels JW, Stott R: Virus removal in a pilot-scale "advanced" pond system as indicated by somatic and F-RNA bacteriophage. Water Sci Technol 2005, 5 I: 107-II0.

43. Toranzos GA, McFeters GA, Borrego J, Savill M: Detection of microorganisms in environmental freshwaters and drinking water. In Manual of Environmental Microbiology Edited by: Hurst CJ, Crawfortd RL, Garland JL, Lipson DA, Mills AL, Stetzenbach LD. Washington D. C.: ASM Press; 2007:249-264.

44. Burlingame GA, McElhany J, Bennett M, Pipes WO: Bacterial interference with coliform colony sheen production on membrane filters. Appl Environ Microbiol 1984, 47:56-60.

45. Chao KK, Chao CC, Chao WL: Suitability of the traditional microbial indicators and their enumerating methods in the assessment of fecal pollution of subtropical freshwater environments. J Microbiol Immunol Infect 2003, 36:288-293.

46. DOF: Norma Oficial Mexicana, NOM-00 I-SEMARNAT- 1996. Que establece los límites máximos permisibles de contaminantes en las descargas de aguas residuales en aguas y bienes nacionales. México, D. F., 6 de enero 1997.

47. Mandilara GD, Smeti EM, Mavridou AT, Lambiri MP, Vatopoulos AC, Rigas FP: Correlation between bacterial indicators and bacteriophages in sewage and sludge. FEMS Microbiol Lett 2006, 263: $119-126$.

48. Ashbolt NJ, Grabow WOK, Snozzi M: Indicators of microbia water quality. In Water quality - Guidelines, standards and health Edited by: Fewtrell L, Bartram J. London: IWA Publishing; 200I:289-316.

49. Borrego JJ, Córnax R, Moriñigo MA, Martínez-Manzanares E, Romero $P$ : Coliphages as an indicator of fecal pollution in water. Their survival and productive infectivity in natural aquatic environments. Wat Res 1990, 24: III-1 I6.

50. Gerba C: Phage as indicators of fecal pollution. In Phage Ecology Edited by: Goyal SM, Gerba CP, Bitton G. New York: Wiley-Interscience; 1987:197-209.

51. Duran AE, Muniesa M, Moce-Llivina L, Campos C, Jofre J, Lucena F: Usefulness of different groups of bacteriophages as model micro-organisms for evaluating chlorination. J Appl Microbiol 2003, 95:29-37.

52. Shin GA, Sobsey MD: Reduction of Norwalk virus, poliovirus I, and bacteriophage MS2 by ozone disinfection of water. Appl Environ Microbiol 2003, 69:3975-3978.

53. DOF: Norma Oficial Mexicana, NOM-003-SEMARNAT-I 997. Que establece los límites máximos permisibles de contaminantes para las aguas residuales tratadas que se reusen en servicios al público. México, D. F., 21 de septiembre 1998.

54. DOF: Ley Federal de Derechos. Disposiciones aplicables en materia de aguas nacionales 2005. Capítulo VIII. Agua. Méx ico, D. F., I de diciembre 2004:186-189.

55. DOF: Norma Oficial Mexicana, NMX-AA-I02-SCFI-2006. Calidad de Agua - Detección Enumeración de Organismos Coliformes, Organismos Coliformes Termotolerantes y Escherichia coli Presuntiva- Método de Filtración en Membrana. México, D. F., 21 de agosto 2006.

56. World Health Organization: Health guidelines for the use of wastewater in agriculture and aquaculture. In Geneva: WHO Technical Report Series 778 WHO Press; 1989.

57. Rzezutka $A$, Cook N: Survival of human enteric viruses in the environment and food. FEMS Microbiol Rev 2004, 28:44I-453.

58. Koopmans $M$, Vennema H, Heersma $H$, van Strien E, van Duynhoven Y, Brown D, Reacher M, Lopman B, European Consortium on Food borne Viruses: Early identification of common-source foodborne virus outbreaks in Europe. Emerg Infect Dis 2003, 9: I|36-I|42.
Publish with Biomed Central and every scientist can read your work free of charge

"BioMed Central will be the most significant development for disseminating the results of biomedical research in our lifetime. "

Sir Paul Nurse, Cancer Research UK

Your research papers will be:

- available free of charge to the entire biomedical community

- peer reviewed and published immediately upon acceptance

- cited in PubMed and archived on PubMed Central

- yours - you keep the copyright

Submit your manuscript here:

http://www.biomedcentral.com/info/publishing_adv.asp 